\title{
Analysis of Performance of Pharmaceutical Drug Distribution Officers Using AHP and Rating Scale Methods in Hospital Bhayangkara Installation, Medan
}

\author{
Agnesh Ribka Theresya Sinulingga ${ }^{1}$, Sri Lestari Ramadhani Nasution ${ }^{2}$, \\ Ali Napiah Nasution ${ }^{3}$, Ermi Girsang ${ }^{4}$ \\ ${ }^{1,2,3,4}$ Master Public Health, Faculty of Medical, Universitas Prima Indonesia, Medan, North Sumatera, Indonesia \\ Corresponding Author: Ermi Girsang
}

\begin{abstract}
Pharmacy staff is a health service that needs to improve the quality of its service to answering customer expectations and demands. AHP (Analytical Hierarchy Process) and Rating Scale are powerful instruments as evaluation tools in management because they can assess the performance of the Hospital Pharmacy Installation. This study aims to analyze the performance of pharmacy officers in drug distribution using the AHP (Analytical Hierarchy Process) method and the Rating Scale at Bhayangkara Hospital Medan in 2020. This type of research is quantitative research. The research design uses a correlation study with a retrospective approach equipped with a sheet. Observations are in the form of a table list. The sample in this research is all officers involved in the distribution of drugs in the inpatient room of the Bhayangkara Hospital Medan who receive drug distribution from the pharmacy. The sampling technique in this study used a total sampling technique, namely taking a sample of the entire population in the study. Based on the sampling technique, the total sample was 57 people. The results of the cross table between the performance of pharmacy officers in drug distribution using the Rating Scale method in the Bhayangkara Hospital Installation in Medan in 2020, which shows the p-value for each variable, namely the quality $p$-value $=0.000$, the quantity value $\mathrm{p}=0.006$, the use time value $\mathrm{p}=$ 0.000 , the cooperation value $p=0.000$. This study concludes that there is an influence between the performance of pharmacy officers in drug distribution using the AHP method and
\end{abstract}

the Rating Scale at the Bhayangkara Hospital Installation in Medan in 2020. It is recommended that pharmaceutical officers further improve health services, especially paying attention to drug distribution for each installation in the hospital.

Keywords: Performance, AHP, Rating Scale, Pharmacy Officers

\section{INTRODUCTION}

To create reliable human resources, good and sustainable human resource management is needed. One of the best ways to manage human resources is through employee performance appraisals or performance appraisals. (Wirawan, 2018). The performance achieved can be seen in quality and quantity by an employee in carrying out their duties and responsibilities. Performance appraisal is the most reliable tool for nurse managers to control human resources and productivity.

The performance appraisal process can be used effectively to direct employee behavior to produce high-quality and quantity-based nursing services. (Simamora, 2014 Performance appraisal is the process by which the organization evaluates the performance of the individual's work. Performance appraisal can be carried out to provide information about the promotion, problems that occur, and the determination of employee salaries. Employee competence 
can be measured by conducting a performance appraisal. (Sinambela 2015)

Management of drug distribution is a very important system in supporting the management and supply of goods and services in pharmaceutical installations. Poor drug distribution will have an impact on the performance appraisal of pharmacy officers Pharmaceutical services in hospitals are an inseparable part of the hospital health service system which is oriented towards patient care, the provision of quality and affordable pharmaceutical preparations, medical devices, and consumable medical materials for all levels of society including clinical pharmacy services. The supply system in health institutions is very important in supporting the management of goods and services. The most important role in the inventory system is to streamline operational activities. (Ministry of Health, 2016).

Based on a preliminary survey conducted by researchers using the interview method to the person in charge of the pharmaceutical installation related to the process of distributing drugs from the pharmacy to the inpatient room, several problems were found related to the research title. The problem is that the drug distribution system from pharmacy to rooms is still done manually using a medicine book.

\section{METHOD OF RESEARCH}

This type of research is quantitative research. The research design uses a correlation study with a retrospective approach equipped with an observation sheet in the form of a table list. This study aims to analyze the performance of pharmacy officers in drug distribution using the method (Analytical Hierarchy Process) and Rating Scale at the Bhayangkara Hospital Installation in Medan in 2020.

The populations in this study were all officers involved in drug distribution in all inpatient rooms at Bhayangkara Hospital, Medan. Based on data from medical records, the number of officers involved in drug distribution in all inpatient rooms that received drug distribution from the pharmacy was 57 nurses.

The sampling technique in this study used a total sampling technique, namely taking a sample of the entire population in the study. Based on the sampling technique, a total sample of 57 nurses was obtained.

\section{RESULT}

From the table in below, it can be seen that of the 57 respondents studied, the majority of respondents aged 35-40 years were 21 respondents with a percentage $(36.8 \%)$ and a minority aged $25-30$ years as many as 5 respondents (8.8\%), The majority of respondents were female as many as 40 people $(70.2 \%)$ and a minority of male respondents were 17 people $(29.8 \%)$, for the length of work the majority of respondents had worked $>1$ year as many as 44 people $(77.2 \%)$ and a minority of respondents who have worked for 1 year as many as 13 people $(22.8 \%)$, for education the majority of respondents with a D3 education are 34 people (59.6\%) and a minority of respondents with a nurse education are 23 people $(40.4 \%)$.

Table 1. Frequency Distribution of Respondent Characteristics in the Bhayangkara Hospital Installation in Medan

\begin{tabular}{|l|l|l|l|}
\hline No & Characteristics & Total & Percentage(\%) \\
\hline 1 & Ages & & \\
\hline & $<25$ Years & 12 & 21,1 \\
\hline & $25-30$ Years & 5 & 8,8 \\
\hline & 30-35 Years & 19 & 33,3 \\
\hline & $35-40$ Years & 21 & 36,8 \\
\hline & Total & 57 & 100 \\
\hline 2 & Genders & & \\
\hline & A Man & 17 & 29,8 \\
\hline & Woman & 40 & 70,2 \\
\hline & Total & 57 & 100 \\
\hline 3 & Periods of Work & & \\
\hline & 1 year & 13 & 22,8 \\
\hline & $>1$ years & 44 & 77,2 \\
\hline & Total & 57 & 100 \\
\hline 4 & Education & & \\
\hline & D3 & 34 & 59,6 \\
\hline & Ners & 23 & 40,4 \\
\hline & Total & 57 & 100 \\
\hline
\end{tabular}



using AHP and rating scale methods in Hospital Bhayangkara Installation, Medan.

Tables 2. Distribution of performance officers medicine for distribution medical installation Bhayangkara Hospital Medan At 2020

\begin{tabular}{|l|l|l|l|}
\hline No & Variables & total & Percentages \\
\hline 1 & Quality & & \\
\hline & Good & 12 & 21,1 \\
\hline & Enough & 45 & 78,9 \\
\hline & Total & 57 & 100 \\
\hline 2 & Quantity & & \\
\hline & Good & 18 & 31,6 \\
\hline & Enough & 39 & 68,4 \\
\hline & Total & 57 & 100 \\
\hline 3 & Times & & \\
\hline & Good & 26 & 45,6 \\
\hline & Enough & 31 & 54,4 \\
\hline & Total & 57 & 100 \\
\hline 4 & Collaboration & & \\
\hline & Good & 17 & 29,8 \\
\hline & Enough & 40 & 70,2 \\
\hline & Total & 57 & 100 \\
\hline
\end{tabular}

From the table below it can be seen that of the 57 respondents studied, the majority of respondents answered that the quality was quite good, namely 45 people $(78.9 \%)$ and a minority of respondents answered good quality as many as 12 people $(21.1 \%)$, for the quantity the majority of respondents answered sufficiently both 39 people $(69.4 \%)$ and a minority answered quite well as many as 18 people $(31.6 \%)$, for the use of time the majority of respondents answered quite well as many as 31 people $(54.4 \%)$ and a minority answered well as many as 26 people ( $45.6 \%$ ), for cooperation the majority of respondents answered quite well as many as 40 people (70.2\%) and minorities answered well as many as 17 people $(29.8 \%)$.

Based on the characteristics of pharmacy officers at the Bhayangkara Hospital Installation in Medan, the results showed that the majority of respondents were aged 35-40, the majority of respondents were female, the majority of respondents had worked> 1 year and the majority of respondents had a D3 education.

The results of another study conducted by Satibi, et al. (2018) stated that there was no effect of age, last education, length of practice, and income on pharmacist performance.

The assumption of the researcher explains that age is not a guarantee for someone to have good knowledge and understanding of an object. Even though a person's age is many, it does not guarantee that a person has a good understanding and knowledge.

Length of work is the time travel that a person has towards the job he is doing. The longer a person works, the better the understanding and knowledge he has. The length of work also makes a person more competent in doing various kinds of jobs and responsibilities.

The researcher assumes that the length of work will determine a person's ability to properly understand an object. The longer a person works, the better his understanding and knowledge of an object or new learning method in the world of work will be better. The researcher assumes that education is very important in supporting one's knowledge and understanding of the object or subject to be studied. The higher one's education, the better one's understanding and knowledge of something

Based on the results of research on the performance of pharmacy officers at the Bahayangkara Hospital Installation in Medan, the majority of respondents answered quite good quality, for the quantity of the majority of respondents answered quite well, for time use the majority of respondents answered quite well and for cooperation the majority of respondents answered quite well.

The assumption of the researcher explains that performance appraisal is an indicator that must be carried out appropriately and must be carried out continuously to maintain work quality.

Based on the results of research on the AHP method in drug distribution in the Bahayangkara Hospital Installation, the majority of respondents answered that it was less effective.

According to the researchers' assumptions, the AHP method is very effective in assessing the performance of pharmacy officers in the hospital, besides this method is very easy to use, it can also be a tool that has a measurable truth value and absolute assessment indicators. 
Based on the results of the research that has been done, it explains that the Rating Scale method of the majority of respondents answered that it was less effective.

According to the researchers' assumptions, the Rating method is one of the most effective performance appraisal methods used to assess the performance of pharmacists in hospitals. This method is also the method most often used to assess the performance of officers or employees in an institution, both public and private.

The logistic regression test results tested on the AHP method showed that the time use variable was more influential with $\mathrm{p}=0.008$, which means that there was an effect of time usage on the performance of pharmacy officers in drug distribution using the AHP method.

According to the researchers' assumptions, cooperation and good use of time will be a factor that influences the performance of pharmaceuticals for drug distribution in the hospital to be much better, if cooperation and use of time are not good, the distribution of drugs will be hampered for each installation in the hospital.

The logistic regression results on the Rating Scale method showed that the cooperation variable was more influential with $\mathrm{p}=0.001$, which means that there was an effect of cooperation on the performance of pharmacy officers in drug distribution using the rating scale method.

According to the researcher's assumption, cooperation is needed in an organization to achieve a common goal. With good cooperation, there will be synergy between fellow workers. Conversely, if there is no collaboration, the quality of work will decrease and synergy will not be achieved.

\section{CONCLUSIONS}

Based on the research that has been conducted at the Bhayangkara Hospital in Medan, it can be concluded that:
1. Characteristics of respondents based on the age of the majority of respondents aged 35-40 years, by gender the majority of respondents are female, based on the length of work the majority of respondents have worked $>1$ year and for education, the majority of respondents have a D3 education.

2. The performance of the respondents based on the quality of the majority of the respondents answered that the quality was quite good, based on the quantity the majority of respondents answered quite well, based on the use of time the majority of respondents answered quite well and for cooperation the majority of respondents answered quite well.

3. AHP method shows that the majority of respondents answered that AHP was less effective.

4. The Rating Scale method shows that the majority of respondents answered that the Rating Scale was less effective.

5. There is an influence between the performance of pharmacy officers in drug distribution using the AHP method and the Rating Scale at the Bhayangkara Hospital Installation in Medan in 2020.

6. The result of multivariate analysis through logistic regression test which is tested on the AHP method shows that the time use variable is more influential with $\mathrm{p}=0.008$. The logistic regression results on the Rating Scale method, shows that the cooperation variable is more influential with $\mathrm{p}=0.001$.

\section{REFERENCES}

1. Ahmad Susanto. (2016). Teori Belajar dan Pembelajaran. Jakarta: Prenada Media Group

2. Anwar, Kunniadi. (2013). Prilaku dan Budaya Organisasi Tenaga Kesehtana. Jakarta: Fakultas Kedokteran Uiniversitas Indonesia

3. Arini L, Sulindawati NLGE, Herawati NT. Analisis pengendalian intern terhadap pertsediaan obat untuk pasien Pengguna BPJS (Badan Penyelenggara Jaminan Sosial) Kesehatan di RSUD (Runah Sakit 
Umum Daerah) Kabupaten Buleleng. JIMAT. 2015

4. Evita, S. N., Muizu, W. Z., \& Atmojo, R. T. (2017). Penilaian Kinerja Karyawan dengan Menggunakan Metode Behaviorally Ancjhor dan Rating Scale dan MBO. PEBKIS Vol 9 No 1.

5. Febriawati H. (2016). Manajemen Logistik Farmasi Rumah Sakit. Yogyakarta: Gosyen Publishing, 2013.

6. Ibrahim A, Lolo WA, Citraningtyas. (2016). Evaluasi penyimpanan dan pendistribusian obat di gudang farmasi RSUP Prof. Dr. R. D. Kandou Manado. Pharmacon.

7. Ilhami, R. S., \& Rimantho, D. (2017). Penilaian Kinerja Karyawan dengan Metode AHP dan Rating Scale. Journal Optimasi Sistem Industri Vol 6 No 2.

8. Kementerian Kesehatan. Peraturan Menteri Kesehatan Nomor 72 Tahun 2016 Tentang Standar Pelayanan Kefarmasian Di Rumah Sakit. Jakarta; 2016.

9. Satibi. (2015). Manajemen Obat di Rumah Sakit. Yogyakarta: Gadjah Mada University Press;

10. Sasongko H. (2014). Evaluasi distribusi dan penggunaan obat pada pasien rawat jalan di Instalasi Farmasi Rumah Sakit Ortopedi Prof. DR. R. Soeharso Surakarta [Tesis]. Yogyakarta: Universitas Gajah Mada.

11. Sheina B, Umam MR, Solikah. (2016). Penyimpanan obat di gudang Instalasi Farmasi RS PKU Muhammadiyah Yogyakarta Unit I. Kes Mas.

12. Standar Pelayanan Kefarmasian di Rumah Sakit. Jakarta: Menteri Kesehatan Republik Indonesia, 2017.
13. Simamora, Henry. (2014). Manajemen Sumber Daya Manusia. Yogyakarta: Bagian Penerbitan Sekolah Tinggi Ilmu Ekonomi YKPN

14. Sinambela, Lijan Poltak. (2015). Manajemen Sumber Daya Manusia. PT.Bumi Aksara, Jakarta

15. Saaty, T. L. (2016). Decision Making The Analytical Hierarchy Process. United States of America: McGraw-Hill

16. Santoso, Singgih. (2016). Prilaku Organisasi. Jakarta: Elekmedia Computindo.

17. Sondang P. Siagian. (2016. Manajemen Sumber Daya Manusia, Bumi Aksara, Jakarta.

18. Sekaran, Uma dan Roger Bougie, (2017), Metode Penelitian untuk Bisnis: Pendekatan Pengembangan-Keahlian, Edisi 6, Buku 2, Salemba Empat, Jakarta Selatan

19. Tantangan standar tarif pelayanan kesehatan dalam penyelenggaraan program jaminan kesehatan JKN. Jakarta: Menteri Kesehatan Republik Indonesia, 2014.

20. Triwibowo. (2013). Manajemen pelayanan keperawatan di rumah sakit. Jakarta: TIM.

21. Wirawan. (2018). Manajemen Sumber Daya Manusia Indonesia. Jakarta: PT Raja G

22. rafindo Persada

How to cite this article: Sinulingga ART, Nasution SLR, Nasution AN et.al. Analysis of performance of pharmaceutical drug distribution officers using AHP and rating scale methods in Hospital Bhayangkara Installation, Medan. International Journal of Research and Review. 2021; 8(3): 15-19. 